\title{
Daniele Pevarello
}

\section{The Sentences of Sextus and the Origins of Christian Ascetiscism}

[Die Sentenzen des Sextus und die Ursprünge der christlichen Askese.]

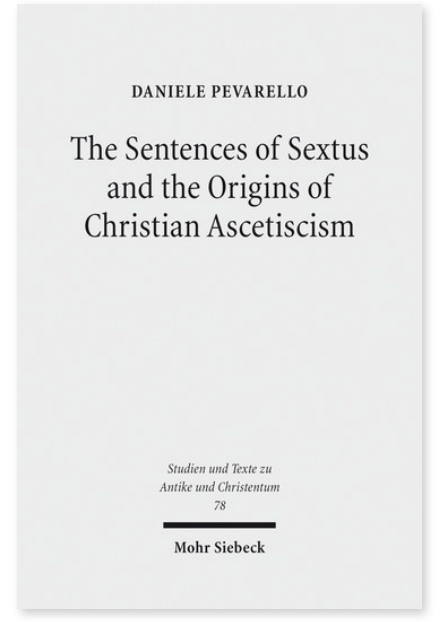

2013. XII, 248 Seiten. STAC 78

ISBN 978-3-16-152686-2

DOI 10.1628/978-3-16-152686-2

BBook PDF $89,00 €$

ISBN 978-3-16-152579-7

fadengeheftete Broschur 89,00
Veröffentlicht auf Englisch.

Daniele Pevarello analysiert die Sentenzen des Sextus, eine Sammlung griechischer Aphorismen aus dem zweiten Jahrhundert, die von Sextus zusammengestellt wurden, einem ansonsten unbekannten christlichen Autor. Das Besondere an Sextus' Sammlung ist die Tatsache, dass die Sentenzen die christliche Neufassung hellenistischer Sprüche sind, von denen einige immer noch in heidnischen Gnomologien und bei Porphyrios erhalten sind. Pevarello untersucht das Problem der Kontinuität und der Diskontinuität zwischen den asketischen Tendenzen des christlichen Übersetzers und den Aphorismen, die in den heidnischen Quellen Selbstbeherrschung propagieren. Er hebt besonders hervor, wie einige Aspekte der stoischen, kynischen, platonischen und pythagoreischen Moraltraditionen, wie zum Beispiel sexuelle Enthaltsamkeit, selbstgewählte Armut, das Schweigegelübde und ein Leben in Abgeschiedenheit, mit Sextus' asketischen Ansichten vor dem Hintergrund der biblischen Traditionen verbunden wurde. Indem er sich auf diese Übernahme von hellenistischen Moraltraditionen stützt, zeigt Pevarello, was für eine bedeutende Rolle die moralische Tradition der griechischen Paideia bei Aufbau und Entwicklung der Selbstbeherrschung unter den frühen christlichen Asketen spielte.

Daniele Pevarello Born 1974; studied Theology (New Testament) at the Waldensian Faculty of Theology (Rome) and at the Kirchliche Hochschule Bethel (Bielefeld); 2012 PhD in Jewish and Early Christian Studies at the Faculty of Divinity of the University of Cambridge; since 2009 Affiliated Lecturer and Tutor in New Testament Greek at the University of Cambridge. https://orcid.org/0000-0002-7255-4470
Jetzt bestellen:

https://mohrsiebeck.com/buch/the-sentences-of-sextus-and-the-origins-of-christian-ascetiscism-9783161526862?no_cache=1 order@mohrsiebeck.com

Telefon: +49 (0)7071-923-17

Telefax: +49 (0)7071-51104 